\title{
Pengembangan Topik Modul Kompetensi Pedagogik Mahasiswa PGSD Universitas Terbuka di Kota Palembang
}

\author{
Alpin Herman Saputra, Ade Mardiana, Teguh \\ Universitas Terbuka \\ alpin.saputra@ecampus.ut.ac.id
}

\section{Sejarah Artikel}

diterima 23/09/2019

\begin{abstract}
Based on the results of the Teacher Competency Examination (UKG) to 6224 elementary school teachers in Palembang, the pedagogical aspect shows a score of 50.70 below the national average of 53.02 or below the minimum competency standard set by 55.5. The purpose of this research is to produce a pedagogical competency topic that can be developed into a program at Universitas Terbuka. Researchers develop based on Permendikbud No. competency standards. 16 of 2017. Research and development topics on the Potential of Students, (2) Learning Theory and Principles of Educating Learning (3) Curriculum Development (4) Learning Methodology (5 (6) Effective Communication (7) Design of Educating Learning (8) Utilization Learning Assessment Results (9) Utilization of Information and Communication Technology (ICT) in Learning (10) Reflections on Learning and Follow Up through Classroom Action Research (CAR).
\end{abstract}

Keyword: pedagogical, competency, topics

\begin{abstract}
Abstrak
Berdasarkan hasil Ujian Kompetensi Guru (UKG) kepada 6224 guru SD di Kota Palembang, pada aspek pedagogik menunjukkan skor 50,70 di bawah rata-rata nasional yaitu 53,02 atau di bawah standar kompetensi minimal yang ditetapkan yakni 55,0. Tujuan penilitian ini adalah menghasilkan topik kompetensi pedagogik yang dapat dikembangkan menjadi program di Universitas Terbuka. Peneliti mengembangkan berdasarkan standar kompetensi Permendikbud No. 16 Tahun 2017. Hasilnya ada 10 topik yaitu, (1) Karakteristik dan Pengembangan Potensi Peserta Didik, (2) Teori Belajar dan Prinsip Pembelajaran yang Mendidik (3) Pengembangan Kurikulum(4) Metodologi Pembelajaran (5) Penilaian Proses dan Hasil Belajar(6) Komunikasi Efektif (7) Perancangan Pembelajaran yang Mendidik (8) Pemanfaatan Hasil Penilaian Pembelajaran (9) Pemanfaatan Teknologi Informasi dan Komunikasi (TIK) dalam Pembelajaran (10) Refleksi Pembelajaran dan Tindak lanjutnya melalui Penelitian Tindakan Kelas (PTK). Kata Kunci: topik, kompetensi, pedagogik
\end{abstract}




\section{PENDAHULUAN}

Fakultas Keguruan dan IImu Pendidikan (FKIP) adalah salah satu fakultas pada Universitas Terbuka (UT) yang menyediakan layanan pendidikan bagi para mahasiswa yang telah bekerja sebagai guru (in-service training) atau tenaga pendidik lainnya. Mahasiswa FKIP sudah memiliki pengalaman dalam bidang mengajar minial satu tahun. UT mengembangkan pendidikan terbuka dan jarak jauh yang unggul. Seluruh program yang ditawarkan oleh FKIPUT telah mendapatkan izin dari Kementerian Riset dan Pendidika Tinggi dan sudah teakreditasi oleh Badan Akreditasi Nasional Perguruan Tinggi (BAN-PT). Pendidikan dengan sistem belajar jarak jauh, mahasiswa dapat belajar kapan dan dimana saja tanpa harus meninggalkan rutinitasnya namun tetap ditutntut untuk memiliki kompetensi belajar mendiri, untuk mendukung proses pembelajaran, mahasiswa diberikan banyak pilihan modus ppembelajaran dengan memanfaatkan teknologi. Keberhasilan studi sepenuhnya ditentukan oleh partisipasi dan belajar mahasiswa. Namun demikian untuk mendukung keberhasilan studi, FKIPUT menyediakan berbagai layanan bantuan belajar seperti tutorial baik tutorial tatap muka maupun tutorial online, konseling, dan bimbingan akademik, latihan mandiri, bahan ajar digital, Massive Open Online Courses (MOOCs), hal tersebut membuat nilai dan kepercayaan masyarakat UT meningkat yang berbading lurus dengan pertumbuhan kuantitas mahasiswa. Data total mahasiswa jurusan Pendidikan Dasar (pendas) UPBJJ palembang per tanggal 17 Juli 2019 melalui laman http://sipelapor.ut.ac.id sebanyak
10.010 mahasiswa, 1439 mahasiswa baru dan 8571 mahasiswa yang mendaftar ulang.

Menurut Undang-undang Nomor 14 Tahun 2005 tentang guru dan dosen disebutkan bahwa guru adalah pendidik profesional dengan tugas utama mendidik, mengajar, membimbing, mengarahkan, melatih, menilai, dan mengevaluasi peserta didik pada pendidikan anak usia dini, jalur pendidikan formal, pendidikan dasar, dan pendidikan menengah. Mahasiswa PGSD UPBJJ UT Palembang adalah guru yang harus dipastikan semua kompetensi (kepribadian, social, profesional dan pedagogik), untuk itu dibutuhkan program pembelajaran yang fokus dan tepat sasaran sebagai upaya pengembangan yang tepat untuk meningkatkan kompetensi guru/ mahaiswa di UT.

Data hasil Ujian Kompetensi Guru (UKG) yang dikeluarkan kemendikbud untuk Kota Palembang terhadap 6224 guru menunjukkan skor 50,70 di bawah rata-rata nasional yaitu 53,02 atau di bawah standar kompetensi minimal yang ditetapkan yakni 55,0. Kondisi tersebut menarik perhatian peneliti untuk mengetahui dan mencoba untuk melalukan penelitian multi years selama 3 tahun, dimana tahun pertama penelitian ini bertujuan untuk mendeskripsikan profil kemampuan pedagogik mahasiswa Universitas Terbuka pada Program Studi Pendidikan Guru Sekolah Dasar (PGSD) khusus di Kota Palembang. Kompetensi pedagogik yang menjadi fokus pada penelitian ini ialah, (1) karakteristik dan pengembangan potensi peserta didik, (2) teori belajar dan prinsip pembelajaran yang 
mendidik, kurikulum, (3)

pembelajaran,

pengembangan metodologi

(5) penilaian proses dan hasil belajar, (6) komunikasi efektif, (7) perancangan pembelajaran yang mendidik. (8) pemanfaatan hasil penilaian pembelajaran,

pemanfaatan TIK

pembelajaran,

dalam

pembelajaran dan tindak lanjutnya melalui PTK. Peneliti berharap penelitian ini dapat menjadi referensi dan bahan pertimbangan perbaikan layanan pembelajaran khusus dalam bidang kompetensi guru.

Kompetensi pedagogik dapat meningkatkan mutu sekolah dengan penentuan strategi yang tepat (Tyagita, 2018). Strategi yang tepat dapat dibuat dengan mendefiniskan masalah secara tepat sasaran. Kompetensi pedagogik juga dapat meningkatkan proses dan hasil pembelajaran yang mendidik. (Othman, 2011) Hasil penelitiannya mendeskripsikan bahwa pendidikan yang mendidik dan menyenangkan berasal dari guru yang menguasai teori dan terampil dalam kompetensi guru, salah satanya adalah kompetensi pedagogik.

Konsep pedagogik adalah gagasan yang memberi warna bagaimana prinsip-prinsip dasar berbuat dan bagaimana melakukan perbuatan mendidik yang harus dipertanggungjawabkan, selaras dengan prinsip-prinsip pengembangan hakikat manusia dan masa depan kehidupan manusia. Marsh (2012) dalam pendahuluannya menyatakan, apa yang seluruhnya harus kita perbuat dalam mendidik? Hal ini memperkuat pemikiran kita, bahwa dalam mendidik anak bangsa, bukan apa yang dapat kita perbuat, tetapi bagaimana kita harus berbuat seoptimal mungkin. Dengan demikian, pedagogik memberikan landasan yang kokoh dalam mempersiapkan calon-calon pendidik untuk mendidik anak bangsa di masa depan yang lebih baik dari hari ini.

Selaras dengan pengertian pedagogik, yaitu membimbing anak dalam mengembangkan kepribadiannya menuju kedewasaan psiko-fisik dan ruhaniahnya yang mengandung pengembangan dimensidimensi individual, sosial, moral dan keberagamaannya (Irwantoro \& Suryana, 2016). Universitas Terbuka sebagai lembaga pendidikan yang membuka kesempatan bagi siapapun yang merasa terpanggil sebagai pendidik, mempunyai tanggung jawab dalam pengembangan ilmu-ilmu yang melandasi bagaimana seharusnya berbuat dan cara berbuat yang inovatif, efektif, dan strategik.

Secara teoritis pedagogik sangat efektif apabila dikelola dalam lingkungan universitas (Tilaar, 2015). Lingkugan kampus merupakan lingkungan belajar yang lengkap bahkan sering disebut miniatur kehidupan. Pedagogik tidak terlepas dari kehidupan bahkan sebaliknya pedagogik dalam pendidikan menjadi penopang dalam semua aspek kehidupan.

Konsep yang dikemukakan oleh Marsh (2012), bahwa mendidik adalah perbuatan yang memikirkan dan mengembangkan seluruh aspek kehidupan manusia, dari mulai konsep manusia, konsep masyarakat, konsep budaya, konsep ilmu, dan konsepkonsep tentang pelayanan pendidikan yang mengembangkan hakikat manusia yang ideal. Hal ini selaras dengan konsep Langeveld (1972), yang menguraikan hakikat anak didik sebagai manusia, dan bagaimana seharusnya pendidik memberikan bimbingan yang selaras dengan 
hakikat pengembangan kemanusiaan. Mendidik adalah mengembangkan konsep-konsep keteladanan, kebersamaan, dan kebijaksanaan. Pedagogik melandasi bagaimana seharusnya kita merancang, mengimplementasikan, dan mengembangkan pendidikan yang berbasis pada filosofi, kebudayaan, dan norma-norma kehidupan bangsa kita yang dalam era perubahan yang sangat cepat selaras dengan perkembangan peradaban dunia dewasa ini. Perubahan yang sangat cepat ini dipengaruhi oleh teknologi komunikasi yang sudah menjadi kebutuhan hidup. Oleh karena itu, kebutuhan hidup masyarakat dewasa ini tidak hanya pada sandang, pangan dan apan, tetapi juga alat komunikasi. Hal ini juga berimbas pada peranan guru dewasa ini, bukan hanya pada P4 (Perencanaan, Pembelajaran, Penilaian dan Pengembangan), tetapi juga kemampuan mengakses informasi melalui jaringan komunikasi internet. Kemampuan-kemampuan yang dibutuhkan masyarakat dewasa ini bukan sekedar mampu berkomunikasi dari perspektif bahasa, tetapi kemampuan-kemampuan yang dibutuhkan dalam serangkaian kebutuhan hidup yang berinteraksi dengan beraneka ragam lingkungan hidup (Purwanto: 2019), dengan demikian kita harus mengembangkan dan memastikan para calon pendidik bahkan pendidik sekalipun harus dibantu layanan belajarnya dengan mudah dengan bantuan topik kompetensi pedagogik.

Kompetensi pedagogik sangat penting bagi guru, terutama dalam upaya memahami karakteristik peserta didik, mengelola (merencanakan, melaksanakan, mengevaluasi, dan menindaklanjuti) pembelajaran, dan mengembangkan berbagai potensi peserta didik secara efektif dan optimal. Kompetensi pedagogik sangat dibutuhkan oleh guru karena guru berhadapan dengan peserta didik yang belum dewasa yang menuntut bukan hanya pengajaran, melainkan juga pengembangan kepribadian peserta didik secara utuh.

Pengambangan topik kompetensi pedagogik ini penting untuk pengembangan program pembelajaran di Universitas Terbuka dan dikaji lebih mendalam karena kompetensi pedagogik yang dievaluasi oleh pemerintah dalam hal ini Kementerian Pendidikan dan Kebudayaan (Kemendikbud) bukan hanya praktik melainkan teori-teori kompetensi Pedagogik. Penelitian ini sebagai landasan awal dalam mengembangkan pembelajaran sistem belajar jarak jauh namun interkasi secara pedagogik tetap menjadi perhatian dari insrtansi terkait, dalam hal ini Universitas Terbuka, sehingga tujuan dari penelitian menghasilkan topik-topik kompetensi pedagogik akan dijadikan menjadi modul/ bahan materi pokok perkuliahan/ buku suplemen untuk menunjang kompetensi pedagogik. 


\section{METODOLOGI}

Metode penelitian yang digunakan oleh peneliti adalah metode survei. Menurut Sugiyono (2013) pengertian metode survei penelitian dilakukan dengan menggunakan kuesioner sebagai instrumen penelitian yang dilakukan pada populasi besar dan kecil, tetapi data yang diteliti adalah data dari sampel yang diambil dari populasi, sehingga ditemukan relatif insiden, distribusi dan hubungan antar variabel, sosiologis dan psikologis. Survei dalam penelitian ini akan diterapkan dengan mengumpulkan informasi tentang kompetensi pedagogik mahasiswa PGSD UT di Kota Palembang. Jumlah sample yang ditentukan sesuai Rumus Slovin adalah 98 mahasiswa yang tersebar di beberapa kelompok belajar di Universitas Terbuka. Pendalaman Model analisis data yang digunakan dalam penelitian ini adalah model analisis interaktif (interactive model analysis) dari Miles dan Huberman. Analisis ini terdiri dari tiga komponen utama, yaitu reduksi data (data reduction),penyajian data (datadisplay), danverifikasi (conclution drawing) Sugiyono, 2009, hlm. 338.

\section{PEMBAHASAN}

Berikut ini adalah hasil penelitian komptensi pedagogik mahasiswa PGSD Universitas Terbuka di Kota Palembang

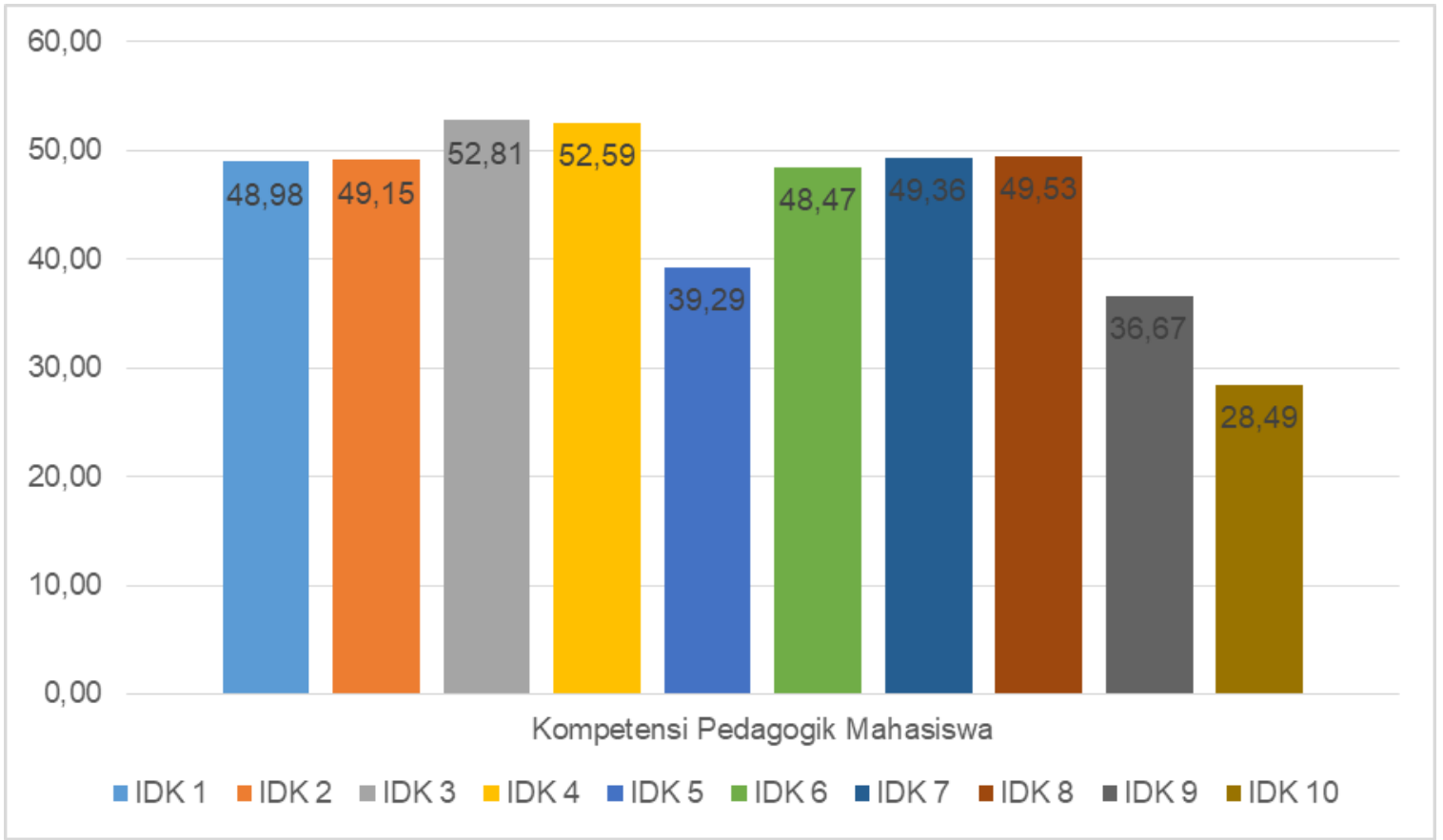

Gambar 1

\section{Keterangan}

IDK 1 Menguasai karakteristik peserta didik dari aspek fisik, moral, sosial, kultural, emosional, dan intelektual.

IDK 2 Menguasai teori belajar dan prinsip-prinsip pembelajaran yang 
mendidik.

IDK 3 Mengembangkan kurikulum yang terkait dengan mata pelajaran/bidang pengembangan yang diampu.

IDK 4 Menyelenggarakan pembelajaran yang mendidik

IDK 5 Memanfaatkan teknologi informasi dan komunikasi untuk kepentingan pembelajaran

IDK 6 Memfasilitasi pengembangan potensi peserta didik untuk mengaktualisasikan berbagai potensi yang dimiliki

IDK 7 Berkomunikasi secara efektif, empatik, dan santun dengan peserta didik

IDK 8 Menyelenggarakan penilaian dan evaluasi proses dan hasil belajar

IDK 9 Memanfaatkan hasil penilaian dan evaluasi untuk kepentingan pembelajaran

IDK 10 Melakukan tindakan reflektif untuk peningkatan kualitas pembelajaran.

Data pada gambar 1 menunjukan semua indikator kompetensi berada di bawah nilai rerata yang ditentukan oleh pemangku kebijkan yaitu 55,00. Kompetensi tidak hanya secara praktik namun juga tetap harus ada teoritis yang melandasinya. Menurut hasil analisis hasil penelitian, yang dibutuhkan oleh pendidik untuk meningkatkan kompetensi pedagogik adalah bahan yang praktis dan mudah untuk memahami serangkaian teori dan implementasi pedagogik pratis sebagai landasan dalam setiap tindakan pembelajaran di kelas maupun pengembangan diri seroang pendidik. Kesepuluh topik yang muncul harus dikemas dalam bentuk outline yang melalui aspek ketebacaan dan kebermaknaan materi untuk pendidik dalam hal ini adalah guru SD. Artikel ini yang akan dibahas secara mendalam dalam topik Karakteristik dan Pengembangan Potensi Peserta Didik. Berikut outline yang dikembangkan. 

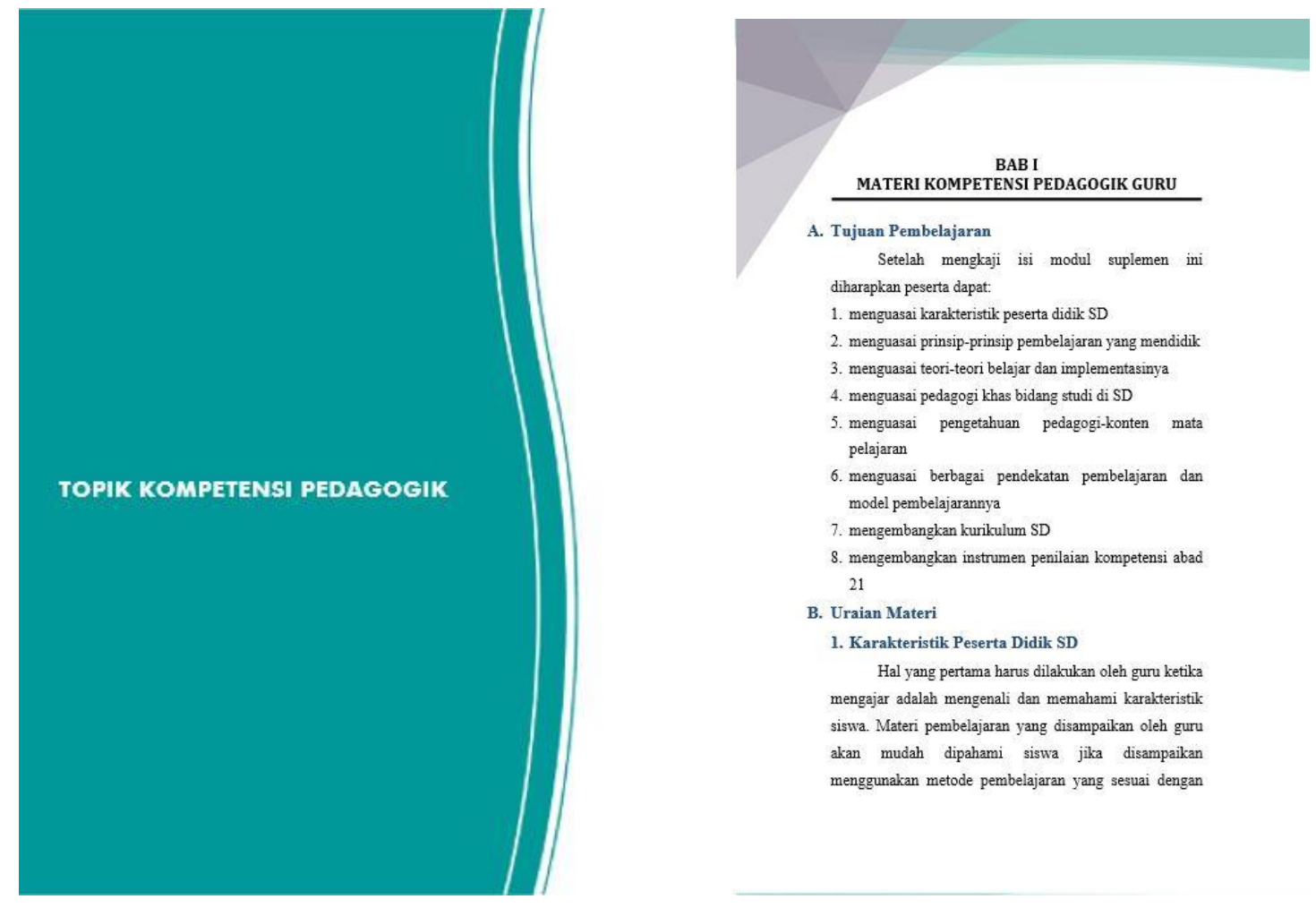

\section{Gambar 1. Outline Topik Pengembangan Kompetensi Pedagogik}

Pengembangan ini dilakukan dalam rangka penyiapan materi-materi pedagogik dan implementasi guna menjawab masalah-masalah yang dihadapi oleh mahasiswa PGSD UT Palembang dalam hal ini juga termasuk ke dalam guru-guru yang ada di daerah Palembang. Berikut ini pengembangan topik kompetensi pedagogik.

\section{Outline Topik Karakteristik dan Pengembangan Potensi Peserta Didik}

1. Pentingnya Menguasai Karakteristik Peserta Didik bagi Guru

2. Kompetensu Guru dalam menguasai Karakteristik

3. Memahami Hakikat Peserta Didik

4. Memahami Karakteristik Peserta Didik

5. Implikasi Karakteristik Peserta Didik bagi Guru
6. Perbedaan Karakteristik Peserta Didik

7. Memahami Karakteristik Perkembangan Peseta Didik

8. Memahami Karakteristik Gaya Belajar Peserta Didik dan Menyelenggarakan Pembelajarannya

\section{Outline Teori Belajar dan Prinsip Pembelajaran yang Mendidik}

1. Pentingnya Penguasaan Teori Belajar dan Prinsip-prinsip Pembelajaran yang Mendidik bagi Guru

2. Komptensi dan Kinerja Guru dalam Menguasai Teori Belajar dan Prinsip-prinsip Pembelajaran yang Mendidik

3. Menguasai Teori Belajar dan Menerapkannya dalam Pembelajaran

4. Menerapkan Prinsip-prinsip Pembelajaran yang Mendidik 
Outline Pengembangan Kurikulum

1. Pentingnya Pengembangan Kurikulum

2. Kompetensi dan Kinerja Guru dalam Pengembangan Kurikulum

3. Memahami Pengembangan Kurikulum 2013

4. Merencanakan Pembelajaran

5. Memahami Konsep Pembelajaran Tematik Integratif di SD

6. Memahami Konsep Pendekatan IImiah dalam Pembelajaran

\section{Outline Metodologi Pembelajaran}

1. Menggunakan Pendekatan Pembelajaran yang Mendidik

2. Menggunakan Pembelajaran yang Mendidik

3. Menggunakan Pembelajaran yang mendidik

\section{Outline Penilaian Proses dan Hasil} Belajar

1. Pentingnya Penilaian dan Evaluasi dalam Pendidikan

2. Kompetensi dan Kinerja dalam Penilaian Evaluasi

3. Memahami Konsep Pengukuran, Penilaian, dan Evaluasi Pembelajaran

4. Menerapkan Prinsip-prinsip dan Persayratan Penilaian dan Evaluasi Pembelajaran

5. Menyelenggarakan Evaluasi Hasil Belajar

6. Menyelenggarakan Evaluasi Pembelajaran

7. Melaksanakan Penilaian Autetik sesuai tuntutan Kurikulum 2013

8. Merancang Program Remidial dan Pengayaan

\section{Outline Komunikasi Efektif}

1. Pentingnya Komunikasi dengan Peserta Didik

2. Kompetensi dan Kinerja Guru dalam Komunikasi dengan Peserta Didik
3. Komunikasi dengan Peserta Didik dalam Pendidikan

4. Komunikasi yang Efektif dengan Peserta Didik

5. Komunikasi dengan Peserta Didik dalam Pembelajaran sebagai Interkasi Edukatif

6. Pendidikan Berarti Komunikasi Timbal Balik antara Guru dan Peserta Didik

\section{Outline Perancangan dan}

\section{Pelaksanaan Pembelajaran yang}

\section{Mendidik}

1. Pentingnya kegiatan Pembelajaran yang Mendidik

2. Kompetensi dan Kinerja Guru dalam Melaksanakan Kegiatan Pembelajaran yang Mendidik

3. Memahami Konsep Dasar Pembelajaran yang Mendidik

4. Merencanakan dan Melaksanakan Pembelajaran yang Mendidik

5. Menyelenggarakan Pembelajaran yang Sesuai dengan Kebutuhan Peserta Didik

6. Menyusun dan Menggunakan Berbagai Materi Pembelajaran Sesuai dengan Karakteristik Peserta Didik

7. Prinsip dan Bentuk Pengemasan Materi Pembelajaran

8. Pengembangan Materi Pembelajaran

9. Memilih Sumber Belajar dan Media Pembelajaran Sesuai dengan Karakteristik Peserta Didik

\section{Outline Pemanfaatan Hasil}

Penilaian Pembelajaran dalam

Pengembangan Potensi Peserta

\section{Didik}

1. Pentingnya engembangan Potensi Peserta Didik

2. Kompetennsi dan Kinerja Guru dalam Pengembangan Potensi Peserta Didik 
3. Mengembangkan Potensi Peserta didik

4. Menggunakan Pembelajaran Strategi Mengoptimalkan Potensi Peserta didik

5. Mengembangkan Kecerdasan Pesera Didik

6. Menggunakan Pembelajaran Mengembangkan Peserta Didik

\section{Outline Pemanfaatan TIK dalam Pembelajaran}

1. Pentingnya penguasaan TIK dalam proses pembelajaran di era siber

2. Memanfaatkan TIK dalam merencanakan, menalaksanakan dan mengevaluasi pembelajaran

3. Pengembangan pengetahuan guru melalui pemanfaatan TIK

Outline Refleksi Pembelajaran dan Tindak lanjutnya melalui Penelitian Tindakan Kelas (PTK)

1. Pendidik sebagai Peneliti
2. Teori Dasar Penenlitian Tindakan Kelas

3. Linieritas Masalah, Data dan Instrumen PTK

4. Menyusun PTK yang dapat memperbaiki pembelajaran

Hasil penelitian ini membuktikan bahwa harus ada program yang fokus untuk meningkatkan komptensi pedagogik sebagai salah satu komptensi guru. Pengembangan 10 Topik kompetensi dapat menjadi dasar dalam membuat informasi yang mudah dipahami oleh mahasiswa/ calon guru. Informasi ini dapat menjadi landasan dalam pembuatan kebijakan Prorgam Studi Pendidikan Guru Sekolah Dsar (PGSD) di Universitas Terbuka Palembang. Topik-topik kompetensi pedagogik yang dihasilkan dapat dijadikan sebagai topik yang diangkat dalam modul/ bahan materi pokok perkuliahan/ buku suplemen pada mata kuliah pedagogika.

\section{SIMPULAN}

Dari data hasil pengolahan data dapat disimpulkan bahwa kompetensi pedagogik dapat dikembangkan dengan pola pengembangan pedagogik praktis dengan membentuk topik-topik yang implementatif yang dapat dikemas secara sederhana dalam modul/ bahan materi pokok perkuliahan/ buku suplemen pedagogik. Kesepuluh topik yang dibentuk adalah, (1) Karakteristik dan Pengembangan Potensi Peserta Didik kteristik, (2) Teori Belajar dan Prinsip
Pembelajaran yang Mendidik (3) Pengembangan Kurikulum(4) Metodologi Pembelajaran

Penilaian Proses dan Hasil Belajar(6) Komunikasi Efektif (7) Perancangan Pembelajaran yang Mendidik (8) Pemanfaatan Hasil Penilaian Pembelajaran (9) Pemanfaatan Teknologi Informasi dan Komunikasi (TIK) dalam Pembelajaran (10) Refleksi Pembelajaran dan Tindak lanjutnya melalui Penelitian Tindakan Kelas (PTK). 


\section{DAFTAR PUSTAKA}

Gravetter, F.J., \& Wallnau, L.B. (2012)

Essentials of Statistics for the

Behavioral Sciences,

$9 e$.

Canada: Thomson Wadsworth.

Irwantoro, N., \& Suryana, Y. (2016). Kompetensi Pedagogik untuk Peningkatan dan Penilaian Kinerja Guru dalam Rangka Implementasi Kurikulum Nasional. Jakarta: Magenta Media

Kemendikbud. (2019). Hasil Ujian Kompetensi Guru Kota Palembang Tahun 2018. https://npd.kemdikbud.go.id/?app id=ukg

Langeveld, M.J. (1970). Pedagogik Teoritis Sistematis, Penerjemah Simanjuntak, Bandung: CV. Jemmars.

Marsh, Colin. (2010). Becoming A Teacher: Knowledge, skills and Issues $5^{\text {th }}$ Edition. Australia: Pearson Education Australia.

McMillan, J, H, \& Schumacer, S. Pearson New International Edition: Evidence-Based Inquiry $7^{\text {th }}$ Edition. New York: Pearson.

Othman. P. (2011). Pembelajaran Yang Mendidik dan Menyenangkan. Pedagogik Praktis yang Berkualitas. 1(1) hl. 10-17.

Peraturan Menteri Pendidikan dan Kebudayaan. (2014). Permendikbud No. 16 Tahun 2007 tentang Standar Kualifikasi
Akademik dan Kompetensi Guru. Jakarta: Permendikbud.

Purwanto, H. (2019). Upaya Meningkatkan Kompetensi Pedagogik Bertanya melalui Suka Tanya bagi Guru yang Mengajar Peserta Didik Baru di SMA Negeri 1 Dusun Selatan. Pedagogik: Jurnal Pendidikan, 14(1), 65-76. https://doi.org/10.33084/pedagog ik.v14i1.833

Sugiyono. (2013). Statistika Untuk Penelitian Edisi Revisi. Bandung: CV. Alfabeta.

Tilaar, H.A.R., (2015). Pendagogik Teoritis untuk Indonesia. Jakarta: Kompas Media Nusantara.

Tyagita, B.P.A. (2018) . Strategi Peningkatan Kompetensi Pedagogik Guru Untuk Meningkatkan Mutu Sekolah. Jurnal Manajemen Pendidikan. 5(2). HIm. 165-176.

Universitas Terbuka. (2019). Rekap Data Mahasiswa Baru \& Ulang Per Masa 2019.1. http://sipelapor.ut.ac.id/pendas/c ari rkp mhs baru ulang pds?m asa $=20191 \quad$ HYPERLINK "http://sipelapor.ut.ac.id/pendas/c ari rkp mhs baru ulang pds?m asa $=20191$ \&cari"\& HYPERLINK "http://sipelapor.ut.ac.id/pendas/c ari rkp mhs baru ulang pds?m asa $=20191$ \&cari"cari

Undang-undang Republik Indonesia. (2005) UU No. 5 Tahun 2005 tentang Guru dan Dosen. Jakarta: UU RI. 